\title{
Combined use of ultrasound guided infraclavicular block and lateral femoral cutaneous nerve block in upper extremity reconstruction requiring large skin graft: case report
}

\author{
Geniş cilt grefti gerektiren üst ekstremite rekonstrüksiyonunda ultrason \\ rebberliğinde infraklavikular blok ve lateral femoral kutanöz sinir blok \\ uygulamasinın kombine kullanımı: Olgu sunumu
}

\author{
Alper KILIÇASLAN, ${ }^{1}$ Atilla EROL, ${ }^{1}$ Ahmet TOPAL, ${ }^{1}$ \\ Muhammed Nebil SELIMOGLU, ${ }^{2}$ Şeref OTELCIOGLU'
}

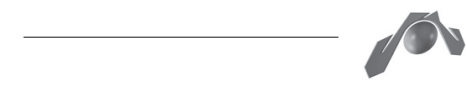

\begin{abstract}
Summary
Combined nerve blocks of the upper extremity and lower limb in same operation rarely performed due to the risk of systemic toxicity of local anesthetics. Therefore, general anesthesia is generally preferred in this operations. However, use of ultrasound allows reliable deposition of the anesthetic around the nerves, potentially lowering the local anesthetic requirement. In this case report, we present a 44-year-old, ASA physical status I, male patient who was operated for upper extremity reconstruction requiring skin graft from anterolateral thigh region under ultrasound-guided infraclavicular brachial plexus block and lateral femoral cutaneous nerve block. The block was successful and no block-related complications were noted. We think that combining an ultrasound guided infraclavicular brachial plexus block and a lateral femoral cutaneous nerve block is a clinically useful and safe technique and an alternative anesthetic method for procedures requiring skin grafts for the upper extremity.

Key words: Infraclavicular block; lateral femoral cutaneous nerve block; ultrasound.
\end{abstract}

\section{Özet}

Üst ve alt ekstremite bloklarının aynı ameliyat içinde kombine kullanımı lokal anestetiklerin sistemik toksisite riskinden dolayı nadiren uygulanmaktadır. Bu yüzden bu tür ameliyatlarda genellikle genel anestezi tercib edilmektedir. Ancak ultrason kullanımı sinirlerin etrafında güvenilir anestezik birikimi sağlayarak, imkan dabilinde anestezik ibtiyacı azaltır. Bu yazıda, ultrason rebberliğinde infraklaviküler brakiyal pleksus bloğu ve lateral femoral kütanöz sinir bloğuyla, 44 yaşında erkek, ASA fiziksel durumu I, yan uyluk bölgesinden alınacak olan deri greftiyle üst ekstremite rekonstriksiyonu yapılan bir hasta sunuldu. Blok başarılı oldu ve bloğa bağh komplikasyon görülmedi. Biz ultrason rehberliğinde infraklavikuler brakiyal pleksus bloğu ile lateral femoral kutaneus sinir bloğunun kombine edilmesinin klinik olarak kullanışl ve güvenli bir teknik olduğunu ve üst ekstremitenin deri grefti gerektiren rekonstriksiyonlarında alternatif bir anestezi metodu olduğunu düşünmekteyiz.

Anahtar sözcükler: İnfraklavikular blok; lateral femoral kutanöz sinir bloğu; ultrason.

\footnotetext{
'Department of Anaesthesiology and Intensive Care, Selcuk University Meram Faculty of Medicine, Konya; ${ }^{2}$ Department of Plastic Surgery, Selcuk University Meram Faculty of Medicine, Konya, Turkey 'Selçuk Üniversitesi Meram Tıp Fakültesi, Anesteziyoloji ve Reanimasyon Anabilim Dalı, Konya; 2Selçuk Üniversitesi Meram Tıp Fakültesi, Plastik ve Rekonstrüktif Cerrahi Anabilim Dalı, Konya

Submitted (Başvuru tarihi) 25.10.2011 Accepted after revision (Düzeltme sonrası kabul tarihi) 24.05.2012

Correspondence (İletişim): Dr. Alper Kılıçaslan. Selçuk Üniversitesi Meram Tıp Fakültesi, Anesteziyoloji ve Reanimasyon Anabilim Dalı, 42080 Konya, Turkey. Tel: +90 - 332 - 2236292 e-mail (e-posta): dralperkilicaslan@gmail.com
} 


\section{Introduction}

Combined nerve blocks of the upper extremity and lower limb in same operation rarely performed due to the risk of systemic toxicity of local anesthetics. Therefore, general anesthesia is generally preferred in this operations. However, ultrasound guidance facilitates the reduction of volume due to visualization of the accurate perineural local anaesthetic deposition. ${ }^{[1]}$

The lateral femoral cutaneous nerve block (LFCN) is used for pain control in meralgia paresthetica, and as a regional anesthetic technique. ${ }^{[2,3]}$ The conventional technique of LCNF block has been classically described using anatomic landmarks, but the anatomical diversity of the nerve may be responsible for failure rates as high as $60 \% .{ }^{[4]}$ Ultrasound-guided injections of the LFCN allow for consistent blockade of the nerve with minimal volumes. ${ }^{[5]}$

Infraclavicular approach to the brachial plexus block anesthesia is an alternative to general anesthesia for upper extremity surgery. Ultrasound guided infraclavicular block appears to be associated with high success rate, short onset time and low complication rate. $^{[6]}$

Hence ultrasound guidance is particularly well suited for combinations of peripheral nerve blocks when low volume injections are desired. We report successfully performed combined ultrasound-guided blockade of the LFCN and infraclavicular brachial plexus in a case of graft harvesting from the thigh for upper extremity reconstruction.

\section{Case Report}

We present a case report of a 44-year-old male, ASA physical status I patient who was operated for upper extremity reconstruction of defects after multiple cutaneous leiomyomas (MCL) excision (Fig. 1). The patient requested regional anesthesia for the procedure.

After standard monitoring was applied (electrocardiogram, pulse oximetry, and noninvasive blood pressure) the patient was sedated with iv midazolam $2 \mathrm{mg}$ and fentanyl $100 \mathrm{mcg}$.

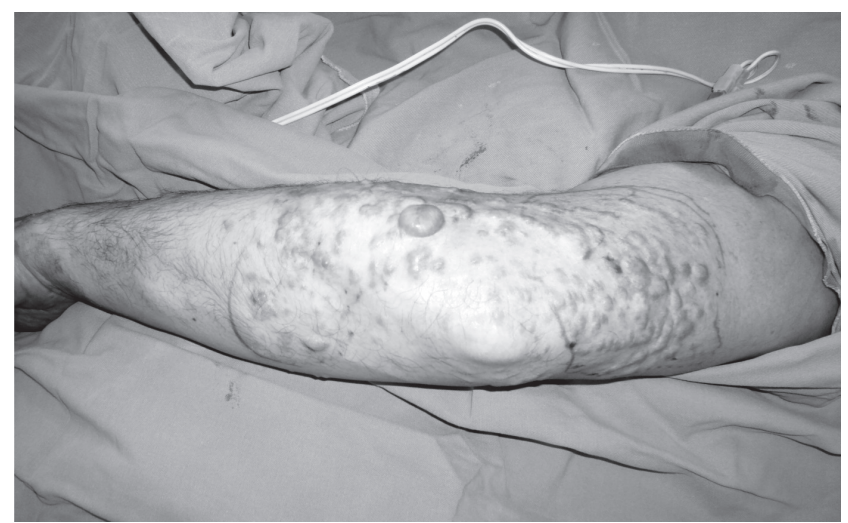

Figure 1. Multiple cutaneous leiomyomas on the left arm.

\section{Infraclavicular block}

The block was performed with the patient lying supine and arm was placed in a neutral position (adducted). After sterile preparation the coracoid process was identified by palpation. The ultrasound probe was placed immediately adjacent to the most medial point of the coracoid process and just below the clavicle about $1 \mathrm{~cm}$ inferior to the site of needle entry as previously described by Gürkan et al. ${ }^{[7]} \mathrm{GE}$ Logic E ultrasound machine (Jiangsu, P.R. China) with a 12L-RS: Large bandwidth, multifrequency linear probe $(5-13 \mathrm{MHz})$ was used during block performance. A 22-gauge (G) $80 \mathrm{~mm}$ insulated nerve stimulation needle (Braun, Germany) was inserted using in-plane technique. Local anesthetic mixture of $13 \mathrm{ml}$ of $0.375 \%$ levobupivacaine and $7 \mathrm{ml}$ of lidocaine $20 \mathrm{mg} / \mathrm{ml}$ with $5 \mu \mathrm{g} / \mathrm{ml}$ epinephrine (total volume $20 \mathrm{ml}$ ) were slowly injected in fractioned doses with frequent aspiration dorsal to axillary artery. Injected local anesthetic could be clearly seen spreading around the cords and axillary artery (Fig. $2 \mathrm{a})$. There was no vascular puncture or any other complication. Successful motor and sensory block of the upper limb occurred within 20 minutes after injection.

\section{Lateral femoral cutaneous nerve block}

After sterile preparation the nerve is visualized lying within the connective tissues between the fascia lata and fascia iliaca as previously described by Hurdle et al. ${ }^{[5]}$ We advanced a $22 \mathrm{G} 50 \mathrm{~mm}$ insulated needle (Braun, Germany) in-plane to the transducer, in a lateral-to-medial direction under direct visualization of needle-tip position and local anesthetic spread on ultrasound imaging (Fig. 2b). Local anesthetic mix- 

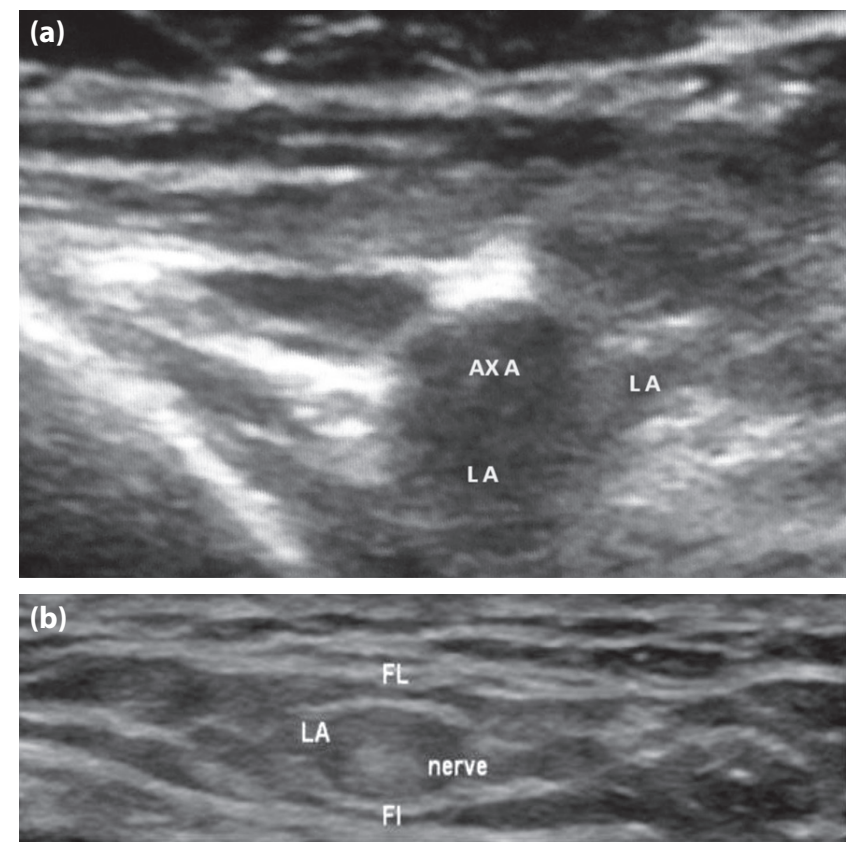

Figure 2. (a) Transverse sonogram in the infraclavicular region showing the spread of local anesthetic. (b) Sonogram of the lateral femoral cutaneous nerve beneath the fascia lata. Ax A: Axillary artery; FL: Fascia lata; FI: Fascia iliaca; LA: Local anesthetic.

ture of $7 \mathrm{ml}$ of $0.375 \%$ levobupivacaine and $3 \mathrm{ml}$ of lidocaine $20 \mathrm{mg} / \mathrm{ml}$ (total volume $10 \mathrm{ml}$ ) were used. The patient had no paresthesia during injection. Assessment of the block was by sensory testing with pinprick 20 minutes after the injection and marked the hypoesthasied area on the lateral thigh with sterile pencil. The patient was discharged home on the second postoperative day without any evidence of neurovasculor injury.

\section{Discussion}

The thigh makes a suitable site for harvesting a split skin graft due to its large surface area and accessibility. There are several pain relief methods alternative to general anesthesia for harvesting split skin graft from the thigh. Percutaneous local anesthetic cream has been used for graft harvesting. ${ }^{[8]}$ It has the obvious advantage of painless application but requires prolonged application times (approximately 2 hours) before the procedure. Local anesthetic infiltration can be used for donor site anesthesia but this is a very painful procedure and requires large amount of drug. The LFCN block has advantages over infiltration and percutaneous local anesthetic cream, in that it requires less solution to anesthetize a larger area and acts faster. The injection site of LCFN is well away from the main neurovascular structures making intravascular injection or neurovascular damage unlikely. ${ }^{[9]}$

Because of the anatomical variability of the LFCN, there have been many methods suggested for blind blocks. ${ }^{[3,4]}$ Ultrasound usage has increased dramatically in the area of regional anesthesia since it can detect small peripheral nerves by new ultrasound equipment and higher frequency probes. $\mathrm{Ng}$ et al. ${ }^{[10]}$ investigated whether accuracy of ultrasound compared with anatomical landmarks in identifying the LFCN in human cadavers and volunteers. Location accuracy using anatomical landmarks was $5.3 \%$ in cadavers and $0 \%$ in volunteers, while accuracy of the ultrasound was $84.2 \%$ in cadavers and $80 \%$ in volunteers. Their study demonstrated that the identification of the LFCN by ultrasound is technically feasible and more accurate than anatomical landmarks.

Blind LFCN blocks use high volume of local anesthetics. Ultrasound guided LCFN block requires a low dose of the local anaesthetic drugs and therefore may be used in combination with other peripheral nerve blocks. While in ultrasound guided LFCN blocks, a volume of 10-15 mL of local anesthetic have been advocated. ${ }^{[1]}$ We were successfull in blocking ultrasound guidance LFCN with small volumes of anesthetic agents and there were no complications such as a blockade of nearby nerves. Infraclavicular block is an alternative method for providing anesthesia for upper extremity surgery. Following a single injection, almost complete anesthesia for the arm and hand below the shoulder can be provided. A successful brachial plexus block using a nerve stimulator requires large dose and volume of local anesthetic. ${ }^{[12]}$ Usage of ultrasound allows reliable deposition of the anesthetic around the cords of the brachial plexus, potentially lowering the local anesthetic requirement. The reduction in local anesthetic dosage should reduce the risk of systemic toxicity. This may be especially important when simultaneous anesthesia of more than one region of the body is required. According to Sandhu et al. ${ }^{[13]}$ $14 \mathrm{~mL}$ of local anesthetic (half of the conventionally used $30-40 \mathrm{ml}$ doses) under ultrasound guidance is sufficient to produce adequate infraclavicular block in adults. 
In conclusion, we think that combining an ultrasound guided infraclavicular brachial plexus block and a lateral femoral cutaneous nerve block is a clinically useful and safe technique and an anesthetic alternative for procedures requiring skin grafts for the upper extremity lesions from the lateral thigh region.

\section{Conflict-of-interest issues regarding the authorship or article: None declared.}

Peer-review: Externally peer-reviewed.

\section{References}

1. Eichenberger $U$, Stöckli $S$, Marhofer P, Huber G, Willimann P, Kettner SC, et al. Minimal local anesthetic volume for peripheral nerve block: a new ultrasound-guided, nerve dimension-based method. Reg Anesth Pain Med 2009;34(3):242-6.

2. Wardrop PJ, Nishikawa H. Lateral cutaneous nerve of the thigh blockade as primary anaesthesia for harvesting skin grafts. Br J Plast Surg 1995;48(8):597-600.

3. Karacalar A, Karacalar S, Uçkunkaya N, Sahin S, Ozcan B. Combined use of axillary block and lateral femoral cutaneous nerve block in upper-extremity injuries requiring large skin grafts. J Hand Surg Am 1998;23(6):1100-5.

4. Shannon J, Lang SA, Yip RW, Gerard M. Lateral femoral cuta- neous nerve block revisited. A nerve stimulator technique. Reg Anesth 1995;20(2):100-4.

5. Hurdle MF, Weingarten TN, Crisostomo RA, Psimos C, Smith J. Ultrasound-guided blockade of the lateral femoral cutaneous nerve: technical description and review of 10 cases. Arch Phys Med Rehabil 2007;88(10):1362-4.

6. Sandhu NS, Capan LM. Ultrasound-guided infraclavicular brachial plexus block. Br J Anaesth 2002;89(2):254-9.

7. Gürkan Y, Acar S, Solak M, Toker K. Comparison of nerve stimulation vs. ultrasound-guided lateral sagittal infraclavicular block. Acta Anaesthesiol Scand 2008;52(6):851-5.

8. Small J, Wallace RG, Millar R, Woolfson AD, McCafferty DF. Pain-free cutting of split skin grafts by application of a percutaneous local anaesthetic cream. Br J Plast Surg 1988;41(5):539-43.

9. Bodner G, Bernathova M, Galiano K, Putz D, Martinoli C, Felfernig M. Ultrasound of the lateral femoral cutaneous nerve: normal findings in a cadaver and in volunteers. Reg Anesth Pain Med 2009;34(3):265-8.

10. Ng I, Vaghadia H, Choi PT, Helmy N. Ultrasound imaging accurately identifies the lateral femoral cutaneous nerve. Anesth Analg 2008;107(3):1070-4.

11. Brown DL. Atlas of regional anesthesia. 2nd ed. Philadelphia: WB Saunders; 1999. p. 114.

12. Pälve $H$, Kirvelä $O$, Olin $H$, Syvälahti E, Kanto J. Maximum recommended doses of lignocaine are not toxic. $\mathrm{Br} J$ Anaesth 1995;74(6):704-5.

13. Sandhu NS, Bahniwal CS, Capan LM. Feasibility of an infraclavicular block with a reduced volume of lidocaine with sonographic guidance. J Ultrasound Med 2006;25(1):51-6. 